\title{
Neurosurgery and a small section from the Greek myth: the God Pan and Syrinx
}

\author{
Tayfun Hakan
}

Published online: 11 December 2008

(C) Springer-Verlag 2008

\section{Origins of the medical terms}

Syrinx and lumbar hypertrichosis are well-known pathologies in neurosurgery practice. The word Syrinx, from Greek, means "shepherd's pipe"; Syringa of syrinx, from Greek, means "tube, hole, channel, shepherd's pipe" [3, 5, 10, 14]. The word hypertrichosis originates from Greek (Gr.Thrix = hair). As in most of the sciences, many medical terms have origins in the Greek language [17] due largely to the influences of The "Father of Medicine", Hippocrates, and the prominent Greek physician, Galen of Pergamon. He separated medicine from philosophy as the first, and his citizen Galen of Pergamon have great role on this situation $[17,21]$. The scientists who followed, including the Roman Aulus Cornelius Celsus (author of De Medicina and known as Cicero medicorum - the Cicero of doctors), used words that were directly imported from Greek, preserved the words' Greek grammatical endings, Latinized the Greek letters and words, and most importantly translated Greek anatomical terminology into Latin [21]. Today, more than $90 \%$ of medical terms have Greek, Latin, or Greco-Latin origins [17].

\section{History of the word syringomyelia}

Although Hippocratic physicians had knowledge of developmental anomalies related to the lower spine, a Persian physician, Al-Razi (Rhazes, 865-925 AD), was the first to describe a spinal dysraphism, spina bifida [9]. The

\section{T. Hakan $(\bowtie)$}

Neurosurgery Clinic,

Haydarpasa Numune Teaching and Research Hospital, Istanbul, Turkey

e-mail: tayfunhakan@yahoo.com existence of a central canal of the spinal cord was one of the most remarkable of the observations of the French physician and anatomist Charles Estienne [18]. Estienne was a contemporary of famous anatomist Vesilus. In addition to describing many other anatomical structures, Estienne published descriptions of the spine and its ligaments in La Dissection des parties du corps humain in 1546. Eight years later, French physician Jean François Fernel wrote about a canal within the spinal cord in his work, Medicina ad Henricum II [9]. In 1700, Brunner made a description in an autopsy of a child revealing meningomyelocele, syringomyelia, and hydrocephalia [8]. Although Portal described the clinical signs and symptoms of this disease in 1804 [8, 9], Olliver d'Angers was the first who used the term "syringomyelia" to describe the cystic cavitations of the spinal cord in his book Traite de la Moelle Épiniére et de ses Maladies, Paris and Brussels, Crevot (Treatment of medulla spinalis and its diseases) in 1827 [9, 10]. In 1824, a cavitation of the spinal cord in continuity with the fourth ventricle was described by the same author in the book De la Moelle Épiniére et de ses Maladies, Paris, Chez Crivot (Textbook of medulla spinalis and its diseases). He thought syringomyelia was a result of developmental arrest of the spinal cord [8]. Later, in 1856, Stilling demonstrated that the central canal was open in all vertebrates and called the condition as "hydromyelia"; according to him, the term syringomyelia should be used for other spinal cavities [9]. After studies in man and birds, Lebendorff found that the causative factor of these pathologies was a neural tube closing failure during the early fetal life in 1881 [9]. Morgagni (1769), Cleland (1883), Simon, Langhans (1881), Chiari (1891), Arnold (1894), Russell and Donald (1935), and Gardner (1958) are the other scientists that we have to remember in relation with syringomyelia [8-10]. 
Today, syringomyelia is a term used for a cystic cavitation of the spinal cord that is filled with fluid identical or similar to cerebrospinal and extracellular fluid. This cavity may extend to the central canal and may be lined by ependymal cells or gliotic tissue [8]. Syringomyelia continues to be well documented, with many studies of the condition published since the nineteenth century regarding pathophysiology [8], classifications according to pathology or magnetic resonance [12], and the traumatic [3] and nontraumatic [16] origins of the condition. Hypertrichosis is defined as an excess hair growth that is not normal for the age, sex, or race of an individual or for a particular region of the body [20]. Erroneously, in many paper, hypertrichosis is called as "hirsutism"; hirsutism is a pathological condition that have to be accepted as a subclass of hypertrichosis caused by excess androgen sensitive hair growth [2]. Hypertrichosis is classified as congenital or acquired (primary or secondary) and localized or generalized; lumbar hypertrichosis that was mentioned here is a localized and congenital (or primary) form of hypertrichosis [20]. One of the other congenital forms of hypertrichosis is congenital hypertrichosis lanuginosa; it is a rarely seen autosomal dominant disease and is characterized by excess of lanugo hair covering the whole body except palms, soles, and mucous membranes [20]. It is also known as "Ambras syndrome" because paintings of the first recorded case and his family reside in a castle in Ambras, Austria [1]. Lumbosacral hypertrichosis may be occurring as a "faun tail" or a "silky down", a wide, often triangularshaped patch of hair measuring up to several inches in length and found in the lumbosacral region; it is frequently a sign for an underlying spinal dysraphism [6, 7]. Dermatologic findings may be found in more than half of the spinal dysraphisms, and one-third of them may include hypertrichosis [20]. It may be seen as terminal hair termed as faun tail. In cases of spinal dysraphism, various neurologic and/or orthopedic deficits also may accompany this condition [6, 7, 19]. Spinal dysraphism is a term covering all kinds of developmental abnormalities occurring in the midline of the back, including the skin and vertebral bodies [19]. A variety of concurrent lesion associated with spinal dysraphisms includes like hyperpigmentation, a dimple, lipoma, portwine stain, dermoid cyst, lumbosacral dermal sinus, or lumbosacral skin appendage, and recognition of them may be very valuable for leading early diagnosis and appropriate treatment.

\section{Pan in the Greek myth}

Pan (Greek Пóv), the Greek god of shepherds and flocks, mountain wilds, hunting, and rustic music, is likely a unique example of lumbar hypertrichosis (Fig. 1). Clearly,

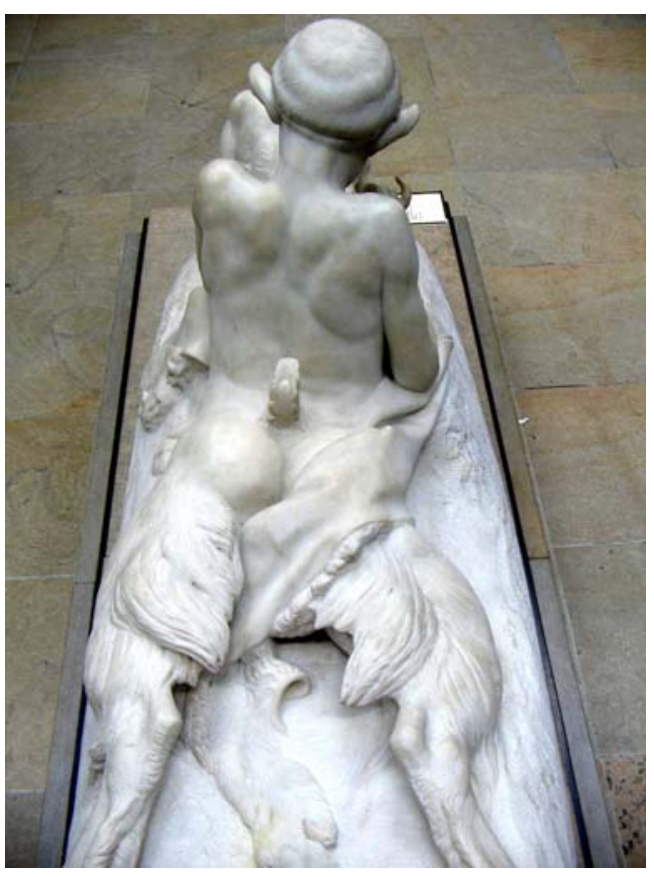

Fig. 1 The sculpture of Pan and bear cubs made by Emmanuel Fremiet in 1867 by courtesy of Musée d'Orsay, Paris, France. View from the back, the faun tail and hindquarters are seen. (Photo by Tayfun Hakan, MD)

he has the identifying faun tail and/or a skin appendage resembling a tail. It has been told that he also has horns of a goat $[4,11,15]$. In some myths, he is the son of Zeus, but generally is known as the son of Hermes and hailed from Arcadia. Classic Greek mythology has accepted that Pan falls in love with a beautiful nymph called Syrinx (Greek $\Sigma v \rho \iota \gamma \xi)$. Not wanting to hear Pan's compliments, the chaste nymph runs away from Mount Lycaeum. Finally, at the bank of the River Ladon, Pan overtakes her. Syrinx calls for help from the water nymphs who turns her into river reeds. A plaintive melody is heard when the air blows through the reeds. Pan takes seven of these reeds, binds them with wax into a panpipe, and plays it in a masterly manner [4]. Today, such a reed flute is called a panpipe or a syrinx. Most of the artists and sculptures characterized Pan with hypertrichosis - faun tail-at his low back and hindquarters. Probably, he had been inspired from a person who had dysraphism with spinal lumbar hypertrichosis and pes cavus deformity, and the artists had had painted or sculptured a man having anatomical signs of a spinal pathology.

The word "panic" also comes from the God Pan [13]. He was considered to be the cause of the sudden fear that sometimes comes for no reason, especially in lonely places. So, we call it as panic (panic, from Greek, Panikon, "pertaining to Pan" in sense of "panic, fright", the source of mysterious sounds that caused contagious, groundless fear in herds and crowds or in people in lonely spots) $[11,13$, 
14]. Syrinx, incidentally, also gave her name to another common medical term, the syringe.

In conclusion, life is a whole, and everything in the world may be a part of it. The legends, myths, fine arts, fiction, history, science, or anything in our world may take place in it. The things and events maybe in a regulation, organization, and harmony, whether we are aware or not. Beside the philosophy that underlines the life, to learn some small, lovely things related with our daily jobs may make it easy to understand and to ease the difficulties that we met.

\section{References}

1. Baumeister FA, Egger J, Schildhauer MT, Stengel-Rutkowski S (1993) Ambras syndrome: delineation of a unique hypertrichosis universalis congenita and association with a balanced pericentric inversion (8) (p11.2; q22). Clin Genet 44(3):121-128

2. Bertolino A, Freedberg I (1993) Hair. In: Fitzpatrick TB, Eisen AZ, Wolff K, Freedberg IM, Austen KF (eds) Dermatology in general medicine. McGraw-Hill, New York, pp 671-696

3. Brodbelt AR, Stoodley MA (2003) Post-traumatic syringomyelia: a review. J Clin Neurosci 10(4):401-408

4. Can S (1997) Classic Greek mythology. Inkilap, Istanbul (in Turkish)

5. Haubrich WS (1984) Medical meanings: a glossary of word origins. Harcourt Brace Jovanovich, San Diego

6. Izci Y, Gonul M, Gonul E (2007) The diagnostic value of skin lesions in split cord malformations. J Clin Neurosci 14(9):860-863

7. Kaya TI, Kokturk A, Guleryuz A, Bagdatoglu C, Ikizoglu G (2002) Faun tail: a rare cutaneous stigma of spinal dysraphism. Int J Dermatol 41(2):119-120
8. Klekamp J (2002) The pathophysiology of syringomyeliahistorical overview and current concept. Acta Neurochir (Wien) 144(7):649-664

9. Laws ER Jr, Udvarhelyi GB (1998) The genesis of neuroscience by A. Earl Walker, American Association of Neurological Surgeons. Park Ridge, IL, pp. 212-213

10. Menezes AH, Smoker WRK, Dyste GN (1990) Syringomyelia, Chiari malformations and hydromyelia. In: Youmans JR (ed) Neurological surgery, vol II. Saunders, Philadelphia, pp 14211459

11. Merivale P (1969) Pan, the Goat-God. His Myth in modern times. Harvard University Press, Cambridge

12. Milhorat TH (2000) Classification of syringomyelia. Neurosurg Focus $15 ; 8(3)$ :E1

13. Nardi AG (2006) Some notes on a historical perspective of panic disorder. J Bras Psiquiatr 55(2):154-160

14. Online etymology dictionary. http://www.etymonline.com/. Accessed 4/23/2008

15. Pan (mythology). http://en.wikipedia.org/wiki/Pan_(mythology). Accessed 4/23/2008

16. Porensky P, Muro K, Ganju A (2007) Nontraumatic cervicothoracic syrinx as a cause of progressive neurologic dysfunction. J Spinal Cord Med 30(3):276-281

17. Soutis M (2006) Ancient Greek terminology in pediatric surgery: about the word meaning. J Pediatr Surg 41(7):13021308

18. Tubbs RS, Salter EG (2006) Charles Estienne (Carolus Stephanus) (ca. 1504-1564): physician and anatomist. Clin Anat 19 (1):4-7

19. Warder DE (2001) Tethered cord syndrome and occult spinal dysraphism. Neurosurg Focus 10(1):E1

20. Wendelin DS, Pope DN, Mallory SB (2003) Hypertrichosis. J Am Acad Dermatol 48(2):161-179

21. Wulff HR (2004) The language of medicine. J R Soc Med 97 (4):187-188 